\title{
Digital Storytelling dan Social Listening : Tren Aktivitas Kehumasan Perguruan Tinggi dalam Pengelolaan Media Sosial
}

\author{
Intan Putri Cahyani1, Yuliani Widianingsih2 \\ 1,2 Program Studi Ilmu Komunikasi Fakultas Ilmu Sosial dan Ilmu Politik \\ UPN Veteran Jakarta \\ 1intanputri@upnvj.ac.id,2yuliani35@yahoo.com
}

\begin{abstract}
ABSTRAK
Pengelolaan informasi publik yang aktif dan responsif menjadi indikator utama dalam perwujudan good governance yang terkait tata kelola komunikasi. Di era digital, media sosial menduduki posisi teratas menjadi layanan yang paling banyak diakses melalui internet sehingga dimanfaatkan oleh Perguruan Tinggi di Indonesia sebagai PR tools yang bisa dijangkau oleh berbagai stakeholder. Praktik Public Relations telah mengalami perubahan fundamental di era disrupsi sehingga peneliti tertarik untuk meneliti tentang tren pengelolaan kehumasan perguruan tinggi saat ini berupa digital storytelling dan social media listening. Tipe penelitian ini adalah deskriptif kualitatif dengan pendekatan netnografi dan memanfaatkan analytical tools yaitu Keyhole dan Social Blade. Objek penelitian difokuskan pada pengelolaan media sosial Perguruan Tinggi yang pernah mendapatkan penghargaan Anugerah Humas di kategori media sosial. Hasil penelitian menunjukkan bahwa praktisi PR Perguruan Tinggi harus menyadari bahwa manusia memiliki kebutuhan untuk berkomunikasi dan terkoneksi antara satu dengan yang lain melalui cerita. Hadirnya berbagai platform di era digital membuat konten digital storytelling dapat dikemas dalam bentuk beragam seperti foto, video, audio, grafis. Sebagai kategori yang memperoleh engagement tinggi dibandingkan kategori lainnya. Perguruan Tinggi memiliki banyak potensi cerita yang dapat dibangun sekaligus dipertukarkan. Dengan kata lain, Perguruan Tinggi memiliki beragam "earning content" dari praktik Digital storytelling yang dilakukan oleh para audiensnya. Social listening yang setara dengan mendengarkan aktif secara online, memungkinkan Humas Perguruan Tinggi untuk lebih dekat dalam memahami apa yang menjadi kebutuhan dan keinginan audiens. Hasil dari Social Listening ini lebih lanjut dapat dimanfaatkan PR untuk dasar melakukan Digital storytelling dalam bermedia sosial. Berinvestasi dengan social media analytical tools bisa menjadi langkah strategis bagi Humas dalam supporting system untuk melaksanakan proses PR dan mencapai tujuan utama yaitu membangun dan memelihara reputasi.
\end{abstract}

Kata kunci : Digital storytelling, Social Listening, Social Media, Analytic Tools, Public Relations 


\begin{abstract}
Active and responsive public information management becomes the main indicator in the realization of good governance related to communication governance. In the digital era, social media occupies the top position to be the most widely accessed service through the internet so that it is utilized by Universities in Indonesia as PR tools that can be reached by various stakeholders. The practice of Public Relations has undergone fundamental changes in the era of disruption so that researchers are interested in researching the current trends in public relations management in the form of digital storytelling and social media listening. This type of research is a qualitative descriptive using netnographic approach and utilizes analytical tools i.e Keyhole and Social Blade. The object of research is focused on the management of Higher Education social media that has been awarded the Public Relations Award in the social media category. The results of the research explain that public relations practitioners of the university must realize that humans need to communicate and connect through stories. The presence of various platforms in the digital age makes digital storytelling content can be built in various forms such as photos, videos, audio, graphics. As a category that gets high engagement compared to other categories. Higher Education has a lot of potential stories that can be built as well as exchanged. In other words, Higher Education has a variety of "earnings content" from the practice of Digital storytelling conducted by its audience. Social listening, which is equivalent to active listening online, enables Higher Education Public Relations to better understand the needs and wants of the audience. The results of this Social Listening can be further utilized by PR to base doing Digital storytelling in social media. Investing in social media analytical tools can be a strategic step for PR in supporting the system to carry out the PR process and achieve the main goal of building and maintaining a reputation.
\end{abstract}

Keywords : Digital storytelling, Social Listening, Social Media, Analytic Tools, Public Relations

\title{
Pendahuluan
}

Sebagai sebuah lembaga penyelenggara pendidikan, Perguruan Tinggi memiliki tanggung jawab untuk melaksanakan good governance dalam tata kelola dan manajemen. Pengelolaan informasi publik yang aktif dan responsif menjadi salah satu indikator utama dalam pemenuhan prinsip profesionalitas, partisipatif, keterbukaan, dan akuntabilitas proses pelayanan publik (Kriyantono, 2015). Oleh karena itu ketersediaan media sosial yang bisa dijangkau seluruh stakeholder menjadi penting. Media sosial yang dikelola oleh Humas Perguruan Tinggi berfungsi sebagai salah satu $P R$ tools yang digunakan dalam membangun reputasi,

Di era digital saat ini, media sosial telah bertransformasi sebagai salah satu sumber informasi yang paling akrab dengan masyarakat. Media sosial hadir dan merubah paradigma masyarakat dalam berkomunikasi dimana batasan jarak, waktu, dan ruang menjadi kabur bahkan hilang(Watie, 2016) 


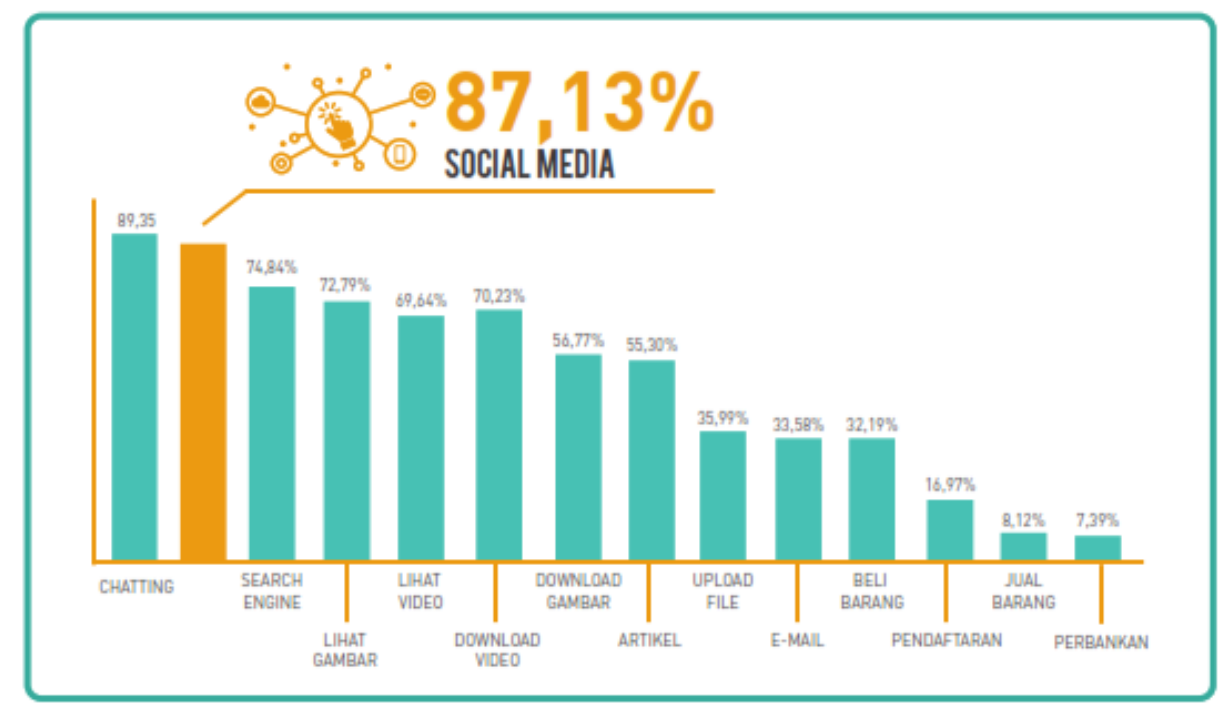

Gambar 1. Layanan yang diakses melalui internet

Sumber : Buku Kominfo : Memaksimalkan Penggunaan Media Sosial dalam Lembaga Pemerintah, 2018

Berdasarkan gambar di atas, saat ini media sosial menduduki posisi teratas menjadi layanan yang paling banyak diakses melalui internet setelah aplikasi chatting. Secara sederhana media sosial didefinisikan sebagai sebuah platform berbasis internet yang mudah digunakan sehingga memungkinkan para pengguna untuk membuat sekaligus berbagi konten yang berisi informasi, opini, dan minat dalam konteks yang beragam seperti konteks informatif, edukatif, sindiran, kritik kepada khalayak yang lebih banyak lagi. Oleh karena itu, media sosial mempunyai efek berantai (multiplier effect) sehingga proses transmisi yang terjadi tidak berhenti pada satu audiens inti saja (Khan, 2017).

Selain website, saat ini bisa dipastikan semua Perguruan Tinggi memiliki media sosial sebagai media komunikasi dengan stakeholder ataupun publiknya. Media sosial yang dimilikipun beragam, seperti Instagram, Youtube, Twitter, LINE, dan media sosial lain yang disesuaikan dengan preferensi masing-masing kampus. Bahkan selama beberapa tahun terakhir, aktivitas Perguruan Tinggi dalam mengelola media sosial mendapatkan perhatian dari Kementerian Riset, Teknologi dan Pendidikan melalui ajang Anugerah Humas.

Dalam mengelola media sosial sebagai bentuk aktivitas PR, pihak humas Perguruan tinggi telah menjalankan fungsi komunikasi yaitu manajemen komunikasi yang didalamnya terdapat unsur Research, Action Planning, Communication, dan Evaluation dengan mempertimbangkan Teori Excellence yang sudah memberikan banyak pengaruh dalam berbagai penelitian kehumasan. Salah satu asumsi teori Excellence menyatakan bahwa 
komunikasi simetris adalah praktik humas yang paling efektif dengan menekankan pada dialogis tanpa meninggalkan etika. Komunikasi simetris ini merepresentasikan orientasi hubungan antara perusahaan dengan stakeholder ataupun publiknya karena menekankan pada terbangunnya mutual understanding (Kriyantono, 2015)

Praktik Public Relations telah mengalami perubahan fundamental di era disrupsi dan terdapat empat hal yang dipastikan akan menjadi tren Public Relations ke depan, yaitu digital storytelling, social listening, big data dan issue management. Storytelling adalah salah satu bentuk komunikasi yang menekankan pada cerita. Ini adalah cara mengkomunikasikan identitas atau peristiwa tertentu, di mana gambar, foto, video dan gambar sering digunakan. Sebaliknya narasi yang digunakan terdiri dari penuturan verbal dari gambar, dengan kata lain, foto itu sendiri tidak cukup untuk menceritakan sebuah cerita (Chalfen, 1987; Miller \& Edwards, 2007). Namun, dengan diperkenalkannya teknologi digital baru, narasinya telah berubah, dan kisah-kisahnya diceritakan dengan menggunakan gambar, foto, video yang dibagikan melalui multiplatform (dalam hal ini sosial media) yang dikenal dengan digital storytelling. Berbagai gambar, foto, dan video itulah yang berbicara sendiri dan mewakili puluhan, ratusan bahkan ribuan kata. (Kurvinen, 2003; Makela, Giller, Tscheligi \& Sefelin, 2000).

Mengelola digital presence media sosial menjadi lebih sulit tidak hanya bagi pengguna media sosial individu namun juga perusahaan, termasuk Perguruan Tinggi. Ada kecenderungan untuk terus menggali berbagai strategi dalam mencari cara untuk mengatur kehadiran online mereka, melibatkan pengguna mereka dalam ruang virtual, memantau peristiwa terkini yang relevan secara efisien dalam waktu nyata, dan mengelola aliran data dan informasi yang diperlukan untuk mengelola hubungan pelanggan melalui internet (Pomputius, 2019)

Selama enam tahun terakhir, beberapa studi menemukan bentuk social listening atau mendengarkan sosial sebagai cara untuk mengatur dan mengawasi kegiatan yang terjadi di luar media sosial organisasi. Selama ini media sosial hanya mengintegrasikan dirinya secara lebih penuh ke dalam kehidupan organisasi, dan social listening menjadi semakin penting untuk memahami tren umum, keterlibatan dengan ide-ide di luar organisasi, serta mendapatkan keuntungan yang strategis dan kompetitif. Berdasarkan hal tersebut, peneliti tertarik untuk melakukan studi terkait tren aktivitas kehumasan perguruan tinggi dalam pengelolaan media sosial berupa digital storytelling dan social media listening.

Berangkat dari teori postmodern dan strategi pemasaran kontemporer, Emily Raymond (2013) mengangkat penelitian dengan judul Dior And Digital storytelling: On The Marketing Of Luxury Brand Narratives. Dalam penelitian ini, digital storytelling ditekankan sebagai sarana virtual yang dengannya sebuah cerita dapat diorganisir. Melalui digital storytelling menunjukkan bahwa individu menghubungkan titik-titik cerita dengan membandingkan "bacaan” mereka dengan yang lain. Untuk mengkonseptualisasikan model 
ini dalam fesyen, penelitian ini mengikuti kampanye Christian Dior's Secret Garden yang menggunakan media Instagram dan YouTube. Berusaha memahami interpretasi konsumen ketika cerita ini berkembang, penelitian ini bertujuan untuk mengukur interaksi media dan audiens dalam parameter analisis jejaring sosial. Dalam temuannya, Emily menunjukkan keberhasilan pemasaran $e$-word-of-mouth, dan menunjukkan kekuatan film fesyen sebagai media komunikasi ilustratif .

Selanjutnya dalam penelitian Garsbo dan Wittberger yang berjudul A Picture is Worth a Thousand Words, saat ini terjadi pergeseran dalam perilaku berkomunikasi manusia. Seiring dengan perkembangan media, kita menyesuaikan diri dengan cara baru yang memungkinkan untuk bersosialisasi satu sama lain. Pada dunia digital yang kita tinggali saat ini, semakin banyak orang terhubung melalui media sosial (LaRose, Connolly, Lee, Li \& Hales, 2014)

Situs jejaring sosial memungkinkan interaksi antar teman serta kemungkinan mendapatkan teman dan kolega baru termasuk di dunia bisnis. Ketika situs jejaring sosial baru muncul dan menjadi populer, perilaku konsumen akan berubah dan beradaptasi dengan seperangkat pedoman baru. Meskipun jejaring sosial adalah semua tentang berkomunikasi, perilaku bersosial media sangat berbeda tergantung pada media dan oleh karena itu penting untuk memahami berbagai jenis perilaku ini (LaRose et al., 2014). Berdasarkan hal tersebut, perusahaan yang telah mulai berinvestasi dalam aktivitas media sosial mencoba untuk meningkatkan keterlibatan pelanggan dan mempererat komunikasi dengan mereka.

Membangun dan memelihara reputasi yang positif dan kuat menjadi tujuan utama seorang praktisi PR. Mengingat reputasi merupakan bentuk investasi jangka panjang yang muncul sebagai faktor penentu bagi keputusan publik tentang sikap dan perilakunya tehadap keberadaan organisasi/produk. Reputasi sebuah Lembaga merepresentasikan "jaringan" reaksi afektif atau emosional baik itu reaksi positif maupun negatif, kuat atau lemah dari multistakeholder terhadap lembaga (Trimanah, 2019). Oleh karena itu dibutuhkan rencana strategi yang tersusun matang dalam proses membangun reputasi berupa alternatif yang dipilih untuk direalisasikan guna mencapai tujuan PR dalam kerangka suatu rencana kehumasan.

Perencanaan PR disusun berdasarkan empat alasan, yaitu (1) menentukan target dan sasaran PR yang nantinya akan menjadi ukuran keberhasilan atas hasil yang telah tercapai, (2) memperhitungkan alokasi sumber daya yang diperlukan dari segi waktu pengerjaan, biaya yang dibutuhkan serta orang-orang yang terlibat, (3) menyusun skala prioritas sesuai dengan tujuan yang ingin dicapai dalam jangka pendek, jangka menengah dan jangka Panjang, dan (4) menerapkan prinsip USGF, yaitu Urgency, Seriousness, Growth, dan Feasibility untuk masing-masing bentuk komunikasi yang akan dilakukan dalam mencapai tujuan. (Trimanah, 2012) 


\section{Metode Penelitian}

Paradigma konstruktivisme menjadi payung besar dalam riset ini dan menggunakan pendekatan deskriptif kualitatif. Jenis penelitian ini memiliki tujuan untuk mendeskripsikan dan menarasikan berbagai fakta dan sifat populasi atau objek tertentu secara sistematis, mendalam dan akurat (Kriyantono, 2020).

Riset kualitatif memiliki prosedur riset dengan menjelaskan fenomena dengan sangat mendetail dan komprehensif melalui pengumpulan data sedalam-dalamnya yang selanjutnya disebut thick description. Dengan kata lain, penelitian ini lebih fous pada kedalaman (holistic/depth) daripada keluasan (breadth). Sedangkan metode yang digunakan dalam riset ini yaitu metode netnografi. Kozinets (2010) berpendapat bahwa netnografi adalah penelitian observasional partisipan yang berbasis di kerja lapangan online yang menggunakan komunikasi komputer untuk sumber data sebagai pencapaian untuk pemahaman etnografi dan representasi dari fenomena budaya atau komunal.

Netnografi sering digunakan sebagai teknik riset komunikasi strategis, yang menggunakan informasi yang tersedia untuk umum di website dan media sosial untuk mengidentifikasi dan memahami kebutuhan kelompok audiens online yang relevan. Netnographer berfungsi untuk mendengarkan, membandingkan, dan memahami cerita tentang bagaimana narasi dibangun dan dibagikan (Kozinets, 2013)

Berdasarkan Kozinets (2010), ada beberapa tahapan yang harus dilalui dalam melakukan studi netnografi. Pertama adalah definisi masalah ataupun topik dari penelitian dan media sosial yang digunakan. Media sosial yang diteliti dalam riset ini antara lain Instagram, Youtube dan Twitter, karena berdasarkan observasi awal, tiga media sosial ini paling diminati audiens dan mendapatkan engagement tertinggi.

Langkah kedua yang dilakukan adalah memilih Perguruan Tinggi yang menjadi fokus penelitian. Disini peneliti fokus kepada Perguruan Tinggi yang mendapatkan Anugerah Humas Kemenristekdikti untuk kategori media sosial dengan penekanan pada pengelolaan dan penyebarluasan informasi kehumasan, serta interaksi dengan pemangku kepentingan instansi melalui media sosial. Dalam netnografi ini, memanfaatkan beberapa analytical tools seperti Keyhole dan Social Blade untuk melakukan monitoring bentuk digital storytelling dan social listening pada media sosial yang digunakan oleh berbagai Perguruan Tinggi. Pengumpulan data dilakukan selama periode tahun 2019. Langkah terakhir yaitu melakukan analisis dan intepretasi dari hasil insight yang didapatkan melalui analytical tools.

Selain itu, wawancara dengan pengelola media sosial berbagai Perguruan Tinggi juga dilakukan guna mengkonfirmasi data utama yang didapatkan dari hasil analytical tools 
supaya goodness criteria dapat terpenuhi dan membantu peneliti untuk mengelaborasi lebih dalam semua data yang didapatkan. Dari data yang telah dikumpulkan, proses selanjutnya adalah analisis dan intepretasi data riset kualitatif. Tahap analisis data memegang peran penting dalam riset kualitatif, yaitu seebagai faktor utama penilaian kualitas tidaknya riset. Dalam riset kualitatif, menggunakan cara berpikir iduktif, yaitu cara berpikir yang berangkat dari hal-hal khusus (fakta empiris) menuju hal-hal yang umum (tataran konsep).

Proses pertama yang dilakukan pada data yang sudah terkumpul adalah dengan melakukan pengklasififikasian atau kategorisasi dengan mempertimbangkan kesahihan data dan selanjutnya dilakukan pemaknaan terhadap data. Pemaknaan ini merupakan prinsip dasar riset kualitatif, yaitu bahwa realitas ada pada pikiran manusia, realitas adalah hasil konstruksi social manusia. Dalam proses ini, berteori penting untuk menghindari blocking interpretation. Pada tahap ini peneliti menjelaskan pola-pola hubungan antar data atau konsep sehingga mengandung makna tertentu (proposisi) secara teoritis, termasuk juga menjelaskan secara teori rancangan model baru, atau pemetaan model. Dari hasil proposi tersebut, termasuk di dalamnya rancangan model, teori baru, hasil pemetaan kemudian ditarik ke dalam simpulan riset (Kriyantono, 2020).

\section{Hasil dan Pembahasan}

\section{Digital storytelling : pendekatan dalam membangun Digital engagement di Media Sosial}

Melalui sejarah, manusia beralih ke cerita untuk menemukan makna dalam berbagai hal. Sebagai makhluk sosial, manusia memiliki kebutuhan untuk berkomunikasi dan terkoneksi antara satu dengan yang lain melalui cerita. Kebutuhan ini tentu saja harus bisa dikelola dengan baik oleh praktisi PR dalam proses menyampaikan pesan komunikasi kepada audiens. Hadirnya berbagai platform yang beragam di era digital membuat audiens dapat dijangkau dengan lebih cepat.

Walaupun saat ini berbagai aktivitas PR sudah cenderung mengarah kepada praktik PR Digital, namun pada prinsipnya tujuan utama dari PR tetap sama yaitu membangun dan memelihara reputasi. Storytelling dalam kaitannya dengan reputasi adalah dengan menceritakan berbagai hal yang telah, sedang dan akan dilakukan oleh sebuah perusahaan ataupun organisasi dalam konteks komunikasi persuasif. Melalui digital storytelling, PR dapat memberikan "sesuatu" yang dibutuhkan dan dinginkan oleh stakeholder.

Desain storytelling melalui media sosial yang dilakukan oleh Humas Perguruan Tinggi dalam setiap unggahannya kebanyakan berupa foto, video ataupun grafis dan dilengkapi dengan caption untuk menguatkan storytelling yang dilakukan. Namun, jika dilihat dengan teliti, unggahan di media sosial secara rutin tersebut masih menonjolkan fungsi informasi daripada fungsi bercerita. Hal tersebut terungkap dalam rilis berita kegiatan yang terlaksana di lingkungan Perguruan Tinggi berupa pengumuman- 
pengumuman kegiatan akademik maupun non-akademik seperti Kuliah Umum, Seminar, PKKMB, Wisuda, Konferensi Ilmiah dan sebagainya.

Teknologi digital memberi peluang dan tantangan baru bagi organisasi masyarakat sipil untuk keterlibatan publik dan politik partisipatif. Berbagai media digital dan rencana strategis merangkai lebih besar gambaran tentang digital engagement. Partisipasi dalam proses membentuk pengaruh sebuah brand dilihat dari berbagai aktivitas yang ada dalam percakapan yang ada di media sosial bisa dilihat dalam gambar berikut

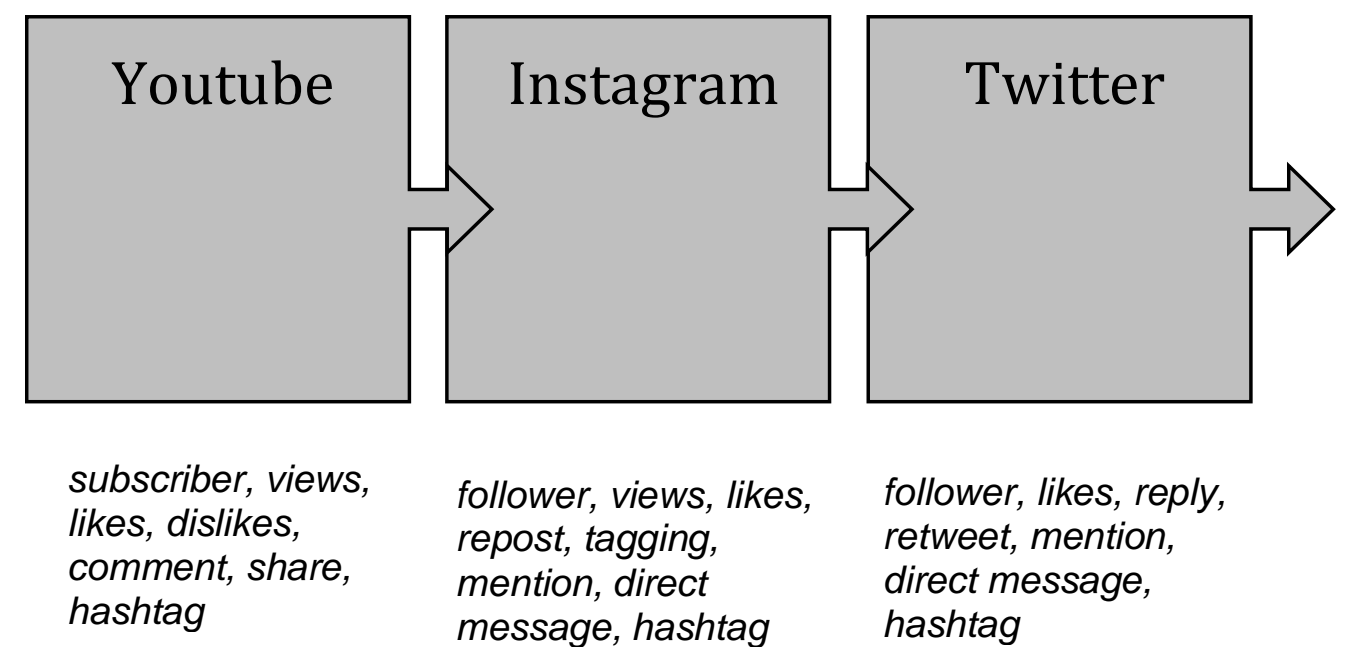

Gambar 2. Bentuk Digital engagement yang terjadi di Media Sosial

Hampir di setiap unggahan media sosial selalu ditemukan komentar dengan proses menandai orang lain dan mengajak untuk membangun sebuah interaksi atau percakapan, ataupun akun lain (influencer) dengan menggunakan berbagai macam tagar seperti \#UNNES, \#UPNVJ, \#UI, \#UPNYK, \#kampusbelanegara ketika melakukan unggahan yang berkaitan dengan kampus yang dimaksud. Oleh karena itu secara tidak langsung, berbagai Perguruan Tinggi telah terbantu dengan micro influencer dari berbagai media sosial yang digunakan, karena mereka turut melakukan digital storytelling dan membangun engagement. 


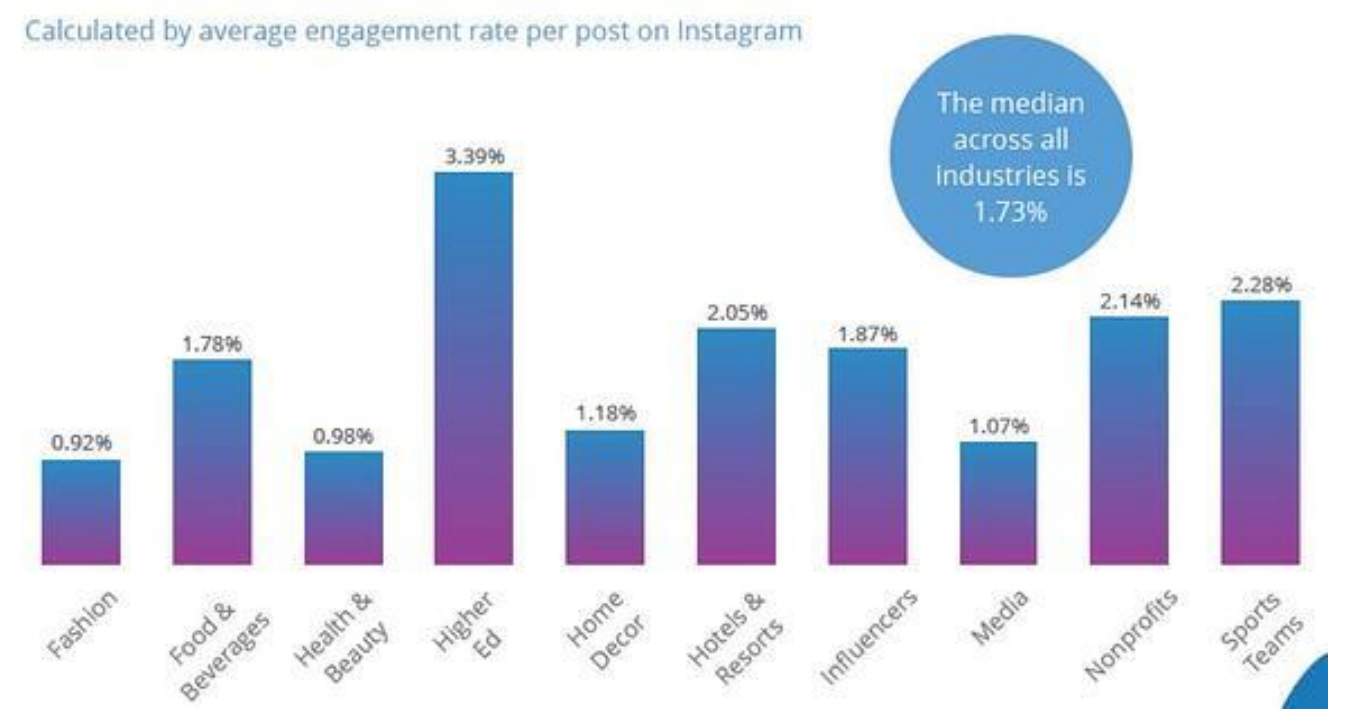

Gambar 3. Rata-Rata Engagament berdasarkan unggahan di Instagram

Berdasarkan gambar di atas, Perguruan Tinggi menduduki kategori tertinggi dalam perolehan engagement dibandingkan kategori lainnya. Hal ini menunjukkan bahwa jumlah target audiens Perguruan Tinggi sangat signifikan, selain itu orang-orang yang relevan dengan Perguruan Tinggi tidak hanya mereka yang sedang menempuh perkuliahan, namun juga calon mahasiswa dan juga para alumni. Ketika sebuah Perguruan Tinggi memiliki reputasi yang bagus, maka sense of belonging akan mengikat dalam diri target audiens yang memperkuat brand resonance sehingga potensi cerita-cerita yang dibangun dan dipertukarkan juga semakin banyak. Dengan kata lain, Perguruan Tinggi memiliki "earning content" dari praktik Digital storytelling yang dilakukan oleh para audiensnya.

Sebagai sebuah produk narasi digital dan perluasan teori penceritaan, digital storytelling adalah praktik berbagi informasi dan penciptaan makna (Irwin, 2014). Dengan menghubungkan titik-titik 'cerita', individu dapat merumuskan makna mereka sendiri dan membangun interpretasi yang lebih besar dengan membandingkan 'bacaan' mereka dengan orang lain. Walaupun cerita-cerita yang dipertukarkan antara produsen dan konsumen itu terkadang tidak saling berhubungan, namun jika dilihat dari perspektif makro, maka akan terdapat benang merah yang yang membentuk episode yang saling terkait dan bermakna. Dari sinilah, reputasi online sebuah organisasi atau perusahaan dapat dibangun.

Kegiatan social tagging atau penandaan sosial ataupun memberikan komentar di platform media sosial, individu dapat berpartisipasi dalam proses membentuk pengaruh sebuah brand. Karena audiens ini terlibat dalam kepentingan bersama dari perwakilan merek (Muñiz dan O'Guinn), digital storytelling juga berfungsi sebagai pintu gerbang untuk aliran komunikasi dua arah dalam parameter komunitas sebuah brand. Di sinilah peran opinion leader dan follower bermunculan. Mereka akan melakukan dan mengatakan apa pun yang diperlukan untuk menyesuaikan dengan citra sebuah organisasi dan untuk membuktikan 
konsistensi dengan apa yang telah mereka katakan dalam 'percakapan' online. Komunikasi percakapan memungkinkan aplikasi metafora yang mudah digunakan dalam bahasa seharihari untuk pengembangan narasi komunikasi persuasive untuk meyakinkan target audiens tentang ekuitas merek sebuah produk atau jasa yang ditawarkan dengan 'bingkai' cerita yang telah dikembangkan oleh pikiran mereka di tingkat bawah sadar, yang merupakan tempat sebagian besar keputusan dibuat.

Berlawanan dengan kontribusi McLuhan terhadap teori komunikasi media massa, logika dari digital storytelling mengasumsikan bahwa 'cerita' pada akhirnya dilakukan ketika pengguna berbagi dan mendiskusikan temuan mereka dengan orang lain. Hal di atas lebih condong pada untuk temuan Gruzd dan Wellman tentang perubahan dari masyarakat yang dipengaruhi secara sosial ke masyarakat yang dipengaruhi jaringan, pengguna tidak lagi terlalu terpengaruh oleh 'media massa' dan justru bergantung pada pendapat para opinion leader dalam jaringan mereka.

Pada dasarnya, storytelling mengkomunikasikan bagaimana dan mengapa kehidupan berubah (McKee, 2003). Sebuah cerita adalah perkembangan substansi yang ditambatkan pada suatu masalah, yang dapat mengikat penonton dengan perasaan dan pemahaman (Bryan, 2011). Storytelling adalah alat yang efektif untuk digunakan, namun cerita harus dipetik secara akurat dan disesuaikan dengan kondisi. Sebagian dari tujuan yang dapat dicapai melalui storytelling adalah untuk memicu aktivitas, menyampaikan identitas, mengirimkan penghargaan, memberi energy perubahan, berbagi pembelajaran, dan memimpin individu ke masa depan (Denning, 2004).

\section{Social listening : Memahami lebih dekat Audiens kita}

Sama seperti ketika kita berkomunikasi, sebelum memulai berbicara atau bercerita kita harus melakukan proses mendengarkan, supaya bagaimana psikologis lawan bicara kita, apa yang sedang mereka alami, serta apa yang menjadi kebutuhan dan keinginan mereka dapat kita pahami secara mendalam. Social listening atau mendengarkan sosial adalah proses aktif menghadiri, mengamati, menafsirkan, dan menanggapi berbagai rangsangan melalui saluran mediasi, elektronik, dan sosial (Stewart \& Arnold, 2018).

Penggunaan frasa yang populer mengacu pada strategi pelacakan percakapan, keluhan, dan tren yang terjadi di sekitar topik atau merek yang diminati melalui berbagai platform media sosial. Mendengarkan memungkinkan organisasi untuk lebih terlibat dengan audiens mereka dan mendengar percakapan seputar apa yang mereka lakukan dengan benar dan bagaimana mereka dapat meningkatkan performance (Pomputius, 2019). Brand menggunakan staretegi social listening untuk mengikuti tren di antara kompetitor, mempelajari minat audiens dalam topik yang berhubungan dan relevan dengan brand tersebut, segera mengatasi keluhan atau umpan balik pengguna, dan mengembangkan pemahaman yang lebih baik tentang percakapan yang lebih besar. 
Dalam pengelolaan media sosial, masih terdapat bias antara social media monitoring dan social listening. Beberapa pihak menyebutkan bahwa social media monitoring mengacu secara ketat pada pelacakan mention dan komentar di media sosial mengenai perusahaan atau organisasi, sedangkan social listening memungkinkan organisasi untuk lebih memahami konteksnya, melalui cara audiens menyebutkan minat, keluhan, dan rekomendasi seputar topik yang diminati perusahaan. Ini memungkinkan perusahaan untuk melihat gambaran tren dan percakapan yang lebih besar dan membuat langkah strategis untuk memenuhi kebutuhan dan perhatian audiens (Parker, 2017).

Social listening saat ini bisa dilakukan dengan memanfaatkan analytical tools yang membantu untuk mendapatkan consumer insight dengan lebih cepat sehingga hasilnya bisa digunakan oleh para praktisi PR untuk merancang strategi komunikasi. Beberapa Perguruan Tinggi di Indonesia seperti Universitas Indonesia, Universitas Pelita Harapan dan Universitas Bina Nusantara saat ini sudah berinvestasi dengan berlangganan analytical tools sebagai support system kegiatan komunikasi mereka. Tampilan analytical tools yang digunakan dalam penelitian ini adalah sebagai berikut

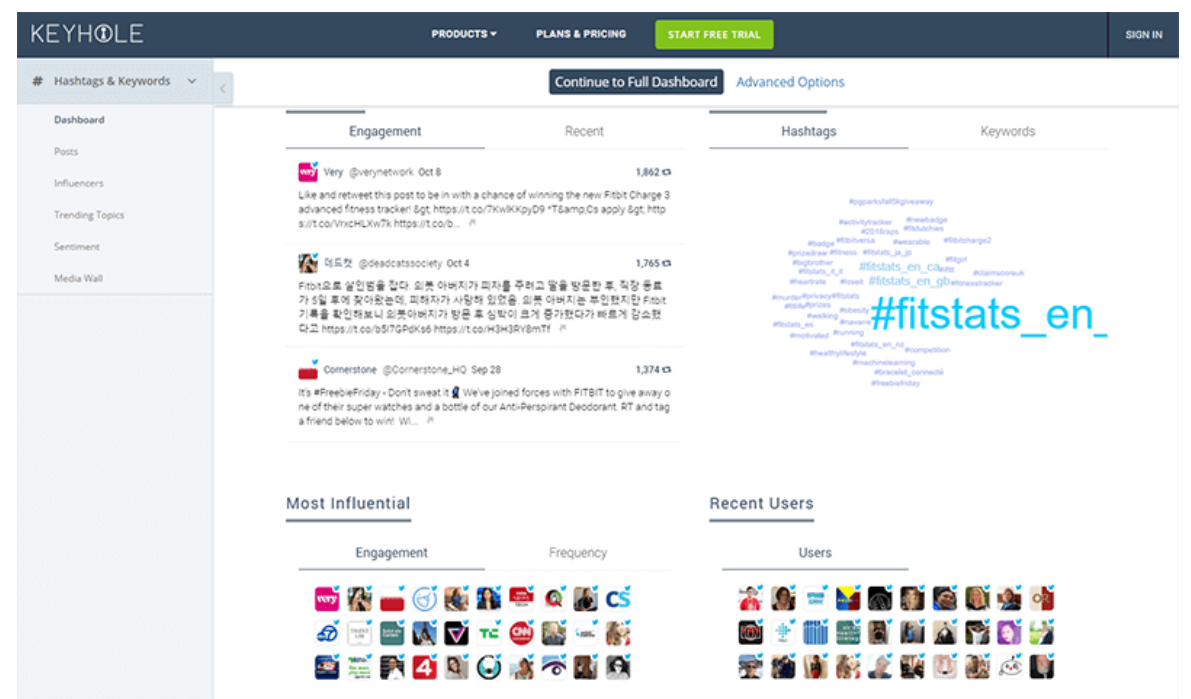

Gambar 4. Keyohole : Analytcal tools yang digunakan untuk Social listening

Keyhole merupakan analytical tools yang bersifat 2-in-1. Dengan tools ini memungkinkan pengelola media sosial untuk mengotomatiskan posting serta melacak kata kunci atau tagar di Twitter dan Instagram. Selain itu, penyebutan brand di seluruh blog dan situs berita dapat dipantau secara real-time. Tools ini dilengkapi dengan sistem analitik juga, termasuk analisis sentimen, kata kunci cloud, dan menyebutkan unsur demografis (terutama geografis) para audiens yang melakukan penandaan sosial (social tangging) ataupun penyebutan sosial (social mention)

Lebih lanjut Keyhole juga mencakup fitur premium seperti melacak siapa saja yang menjadi influencer brand kita, membuka kunci riwayat menyebutkan, dan mendapatkan akses API (Application Programming Interface) ke Keyhole. 
Karena dalam penelitian ini Youtube menjadi media sosial yang ikut diteliti, maka analytical kedua yang digunakan adalah Social Blade.

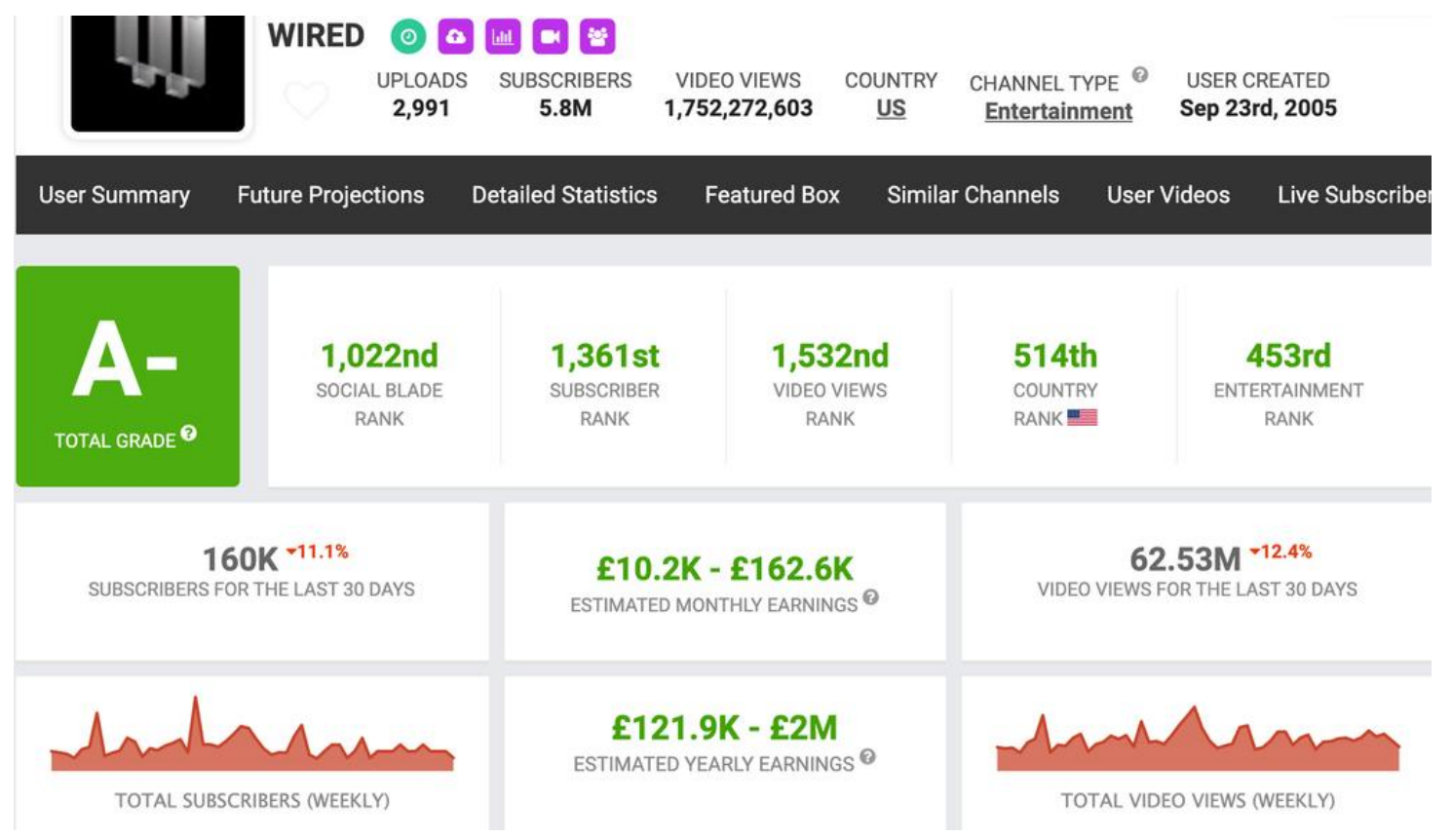

Gambar 5. Social Blade : Analytcal tools yang digunakan untuk Social listening Platform Youtube

Social Blade merupakan tools yang digunakan untuk melacak statistik dan analitik media sosial. Social Blade paling sering digunakan untuk menganalisis platform YouTube, tetapi juga memiliki informasi analitik mengenai Twitch, Instagram, Twitter, dan Facebook. Social Blade memungkinkan pengguna untuk melacak statistik saluran mereka serta tetap terhubung dengan akun online yang mereka ikuti. Pemilik akun dapat melihat pembacaan yang akurat tentang semua angka penting, seperti jumlah pelanggan dan tampilan halaman. Ini adalah tools yang dimaksudkan untuk membuat pemiliki akun Youtube lebih kompetitif dan sadar akan audiens mereka. Selain itu Social Blade juga bisa digunakan untuk memantau pergerakan kompetitir kita dalam media sosial. Namun ada hal utama yang perlu diperhatikan ketika ingin menggunakan tools Social Blade, yaitu hanya bisa dipakai ketika follower atau subscriber kita minimal 1.000 orang. 


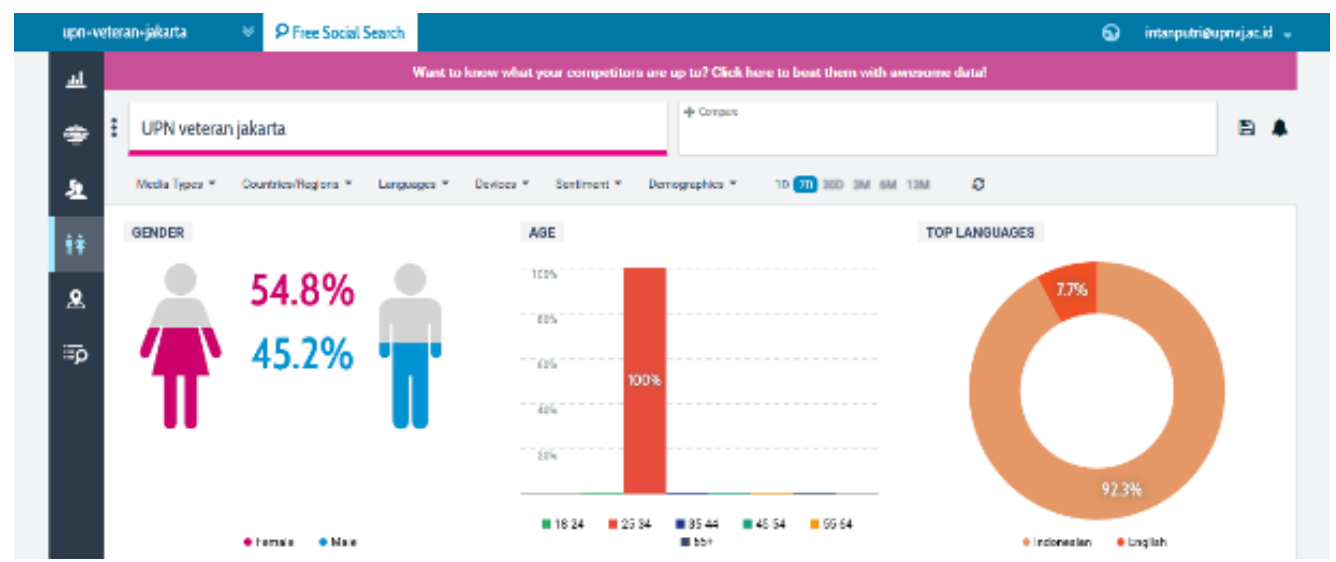

Gambar 6. Infographic of Conversation about UPN Veteran Jakarta on social media

Saat ini Perguruan Tinggi telah berusaha untuk optimal dalam penggunaan semua media sosial, antara lain website, Instagram, Facebook, Twitter, dan Youtube. Folllower dan jumlah subscriber atau follower akun-akun tersebut juga meningkat secara signifikan dari waktu ke waktu. Berdasarkan analytical tools, hasil social listening berupa insight yang didapat bisa membantu pihak Humas Universitas khususnya pengelola media sosial untuk merancang strategi komunikasi yang sesuai dengan target audiens, sebagai contoh seperti yang ada di Gambar 6. Gambar di atas mendeskripsikan tentang infografis mengenai percakapan yang terjadi di media sosial tentang salah satu Peguruan Tinggi yaitu UPN Veteran Jakarta. Sentimen yang terjadi di media sosial juga bisa terpantau melalui analytical tools. Hal ini menjadi sangat penting, karena tujuan utama dari berkomunikasi melalui media sosial adalah membangun digital presence dan juga reputasi online, jadi feedback apa yang kita dapatkan baik itu positif maupun negatif bisa menjadi dasar evaluasi dari Proses PR yang dijalankan oleh Humas Perguruan Tinggi.

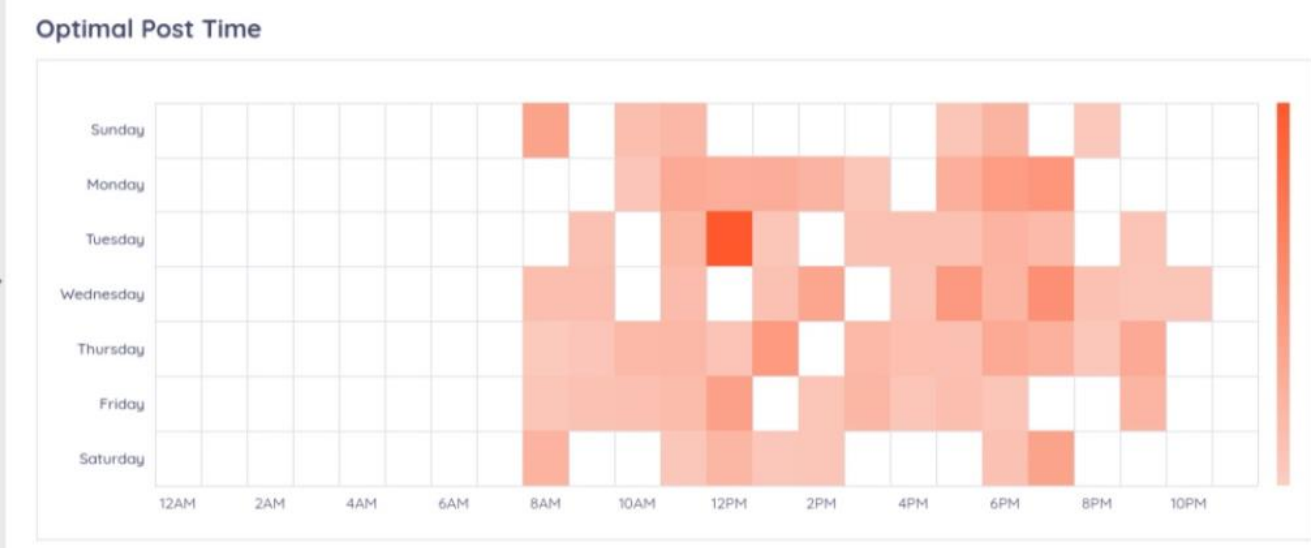

Gambar 7. Optimalisasi waktu unggahan berdasarkan digital engagement

Tidak hanya itu saja, social listening juga bisa membantu lebih lanjut mengenai kapan waktu yang tepat untuk mengunggah sebuah konten di media sosial. Tidak hanya 
berdasarkan hari saja, namun hingga jam atau waktu yang tepat. Hal ini didapatkan berdasarkan hasil evaluasi tentang digital engagement yang telah terjadi di media sosial, semakin tinggi digital engagement yang terjadi secara berulang, maka didapatkan simpulan bahwa mengunggah konten di waktu tersebut dianggap efektif karena mendapatkan perhatian yang besar dari audiens.

\section{Simpulan}

Kebutuhan manusia untuk berkomunikasi dan terkoneksi antara satu dengan yang lain melalui cerita harus bisa dimanfaatkan dengan baik oleh praktisi PR khususnya Humas Perguruan Tinggi untuk menyampaikan pesan komunikasi kepada audiens dengan lebih cepat. Hadirnya berbagai platform yang beragam di era digital membuat konten digital storytelling dapat dikemas dalam bentuk beragam seperti foto, video, audio, grafis. Sebagai kategori yang memperoleh engagement tinggi dibandingkan kategori lainnya. Perguruan Tinggi memiliki banyak potensi cerita yang dapat dibangun sekaligus dipertukarkan. Dengan kata lain, Perguruan Tinggi memiliki "earning content" dari praktik Digital storytelling yang dilakukan oleh para audiensnya.

Social listening yang setara dengan mendengarkan aktif secara online, memungkinkan Humas Perguruan Tinggi untuk mengikuti percakapan, menilai kebutuhan dan keinginan audiens, mengevaluasi program, mengatasi masalah, dan tetap kompetitif di bidang minat mereka tanpa merasa kesusahan dan kewalahan oleh arus informasi yang dipertukarkan dari banyak platform media sosial. Perkembangan teknologi digital harus dimanfaatkan oleh Humas, terutama pengelola media sosial, untuk mendapatkan beragam insight dari audiens melalui analytical tools. Hasil dari Social Listening ini lebih lanjut dapat dimanfaatkan PR untuk dasar melakukan Digital storytelling dalam bermedia sosial. Berinvestasi dengan social media analytical tools bisa menjadi langkah strategis bagi Humas dalam supporting system untuk melaksanakan proses PR dan mencapai tujuan utama yaitu membangun dan memelihara reputasi dalam jangka panjang.

\section{Daftar Pustaka}

Bryan, A. (2011). The new digital storytelling: creating narratives with new media. Santa Barbara: Praeger.

Chalfen, R. (1987). Snapshot versions of life. University of Wisconsin Press.

Denning, S. (2006). The leader's guide to storytelling. John Wiley \& Sons.

Garsbo, Caroline \& Emilia Sorensson Wittberger. A Picture is Worth a Thousand Words : A qualitative analysis of how consumers identify themselves o Instagram. Thesis.Lund University.

Irwin, S. O. (2014). Embodied being: Examining tool use in digital storytelling. Tamara: Journal for Critical Organization Inquiry, 12(2). 
Khan, G. F. (2017). Social media for Government. Springer Books.

Kozinets, R. V. (2010). Netnography: Doing ethnographic research online. Sage publications.

Kozinets, R. V. (2013). Netnography. The international encyclopedia of digital communication and society, 1-8.

Kriyantono, R. (2015). Konstruksi Humas Dalam Tata Kelola Komunikasi Lembaga Pendidikan Tinggi di Era Keterbukaan Informasi Publik. Jurnal Pekommas, 18(2), $117-126$.

LaRose, R., Connolly, R., Lee, H., Li, K., \& Hales, K. D. (2014). Connection overload? A cross cultural study of the consequences of social media connection. Information Systems Management, 31(1), 59-73.

Lund, N. F., Cohen, S. A., \& Scarles, C. (2018). The power of social media storytelling in destination branding. Journal of Destination Marketing and Management, 8(June), 271-280. https://doi.org/10.1016/j.jdmm.2017.05.003

Kriyantono, R. (2020). Innovative Thought of Critical Ethnography in the Dominance of Excellent Theory in the Research and Practice of Public Relations. Tuturlogi: Journal of Southeast Asian Communication, 1(1), 1-11.

Kriyantono, R. (2020). Teknik Praktis Riset Komunikasi. Jakarta: Kencana Prenada Media Group

McKee, R., \& Fryer, B. (2003). Storytelling that moves people. Harvard business review, $81(6), 51-55$.

Miller, A. D., \& Edwards, W. K. (2007, April). Give and take: a study of consumer photosharing culture and practice. In Proceedings of the SIGCHI conference on Human factors in computing systems (pp. 347-356).

Parker, Sarah. "What's the Difference Between Social listening and Monitoring?"

Pomputius, A. (2019). Can You Hear Me Now? Social Listening as a Strategy for Understanding User Needs. Medical Reference Services Quarterly, 38(2), 181-186. https://doi.org/10.1080/02763869.2019.1588042

Raymond, Emily . (2013). Dior And Digital storytelling: On The Marketing Of Luxury Brand Narratives. Thesis. Acadia University.

Stewart, M. C., \& Arnold, C. L. (2018). Defining Social Listening: Recognizing an Emerging Dimension of Listening. International Journal of Listening, 32(2), 85-100. https://doi.org/10.1080/10904018.2017.1330656

Trimanah. (2019). Reputasi Dalam Kerangka Kerja Public Relation. Jurnal Ilmiah Komunikasi Makna, 3(1), 92-102. https://doi.org/10.30659/JIKM.3.1.92-102

Union Metrics. April 26, 2017. https://unionmetrics.com/blog/2017/04/social-listeningmonitoring/. 
Watie, E. D. S. (2016). Komunikasi dan Media Sosial (Communications and Social Media). Jurnal The Messenger, 3(2), 69. https://doi.org/10.26623/themessenger.v3i2.270 